\title{
ВІДІБРАННЯ БІОЛОГІЧНИХ ЗРАЗКІВ ДЛЯ ЕКСПЕРТИЗИ У КРИМІНАЛЬНОМУ ПРОВАДЖЕННІ: ОСНОВНІ ЕТАПИ ТА НАПРЯМИ ДОСЛІДЖЕННЯ
}

Коропецька С. О., Смушак О. М.

У cmammi розглянуто основні етапи та напрями дослідження відібрання біологічних зразків для експертного дослідження у кримінальному процесі. В аналізі акцентується увага на криміналістичних та судово-медичних аспектах означеної проблематики. Констатується, що у практиці розкриття та розслідування злочинів ще на початку XX cm. відбиралися зразки для експертних досліджень, проводилися відповідні порівняльні дослідження, $і$ часом це мало вирішальне юридичне значення. Приховані ж властивості тканин і виділень людини стали виявляти лише після відкриття вченими К. Ландштейнером (1900-1901) та Я. Янським (1907-1908) групових антигенів у крові. Саме тоді кров розділили на чотири групи: 0(1), $A(I I), B(I I I), A B(I V)$. Ця перша генетично поліморфна система дала змогу визначати групову належність досліджуваних об' $є$ тів та стала поштовхом до подальших досягнень у галузі молекулярної біології та розроблення новітніх методів, заснованих на вивченні генетичної інформації - генотипоскопії (ДНК-аналізу), ізофокусуванні, електрофорезу та ін., що дає змогу органам досудового розслідування встановлювати конкретних осіб, у тому числі шляхом відбирання зразків для порівняльного дослідження. 3'ясовано, що окремих наукових досліджень, присвячених отриманню зразків біологічного походження у кримінальному провадженні, не проводилося взагалі, хоча за останні роки було підготовлено декілька наукових робіт, у яких досліджувалися окремі аспекти виявлення, вилучення, зберігання слідів (а не зразків) біологічного походження, а також проведення експертних досліджень слідів та інших об'єктів біологічного походження. Серед науковців варто назвати прізвища І.О. Аїстова, А.Г. Іванова, Т.М. Шамонової, К.В. Левченка та О.С. Арутюнова. На підставі аналізу стану та основних напрямів дослідження отримання зразків для проведення експертизи у кримінальному провадженні виділено періодизацію виникнення та формування поглядів на отримання цих зразків. Особливої актуальності необхідність проведення досліджень із відібрання зразків біологічного походження у кримінальному провадженні набуває у зв'язку з прийняттям сучасного КПК України, підготовленого з урахуванням міжнародних стандартів із прав людини та вимог сьогодення у боротьбі зі злочинністю.

Ключові слова: біологічні зразки, відібрання, ДНК-аналіз, дослідження, експертиза.

Koropetska S. O., Smushak O. M. Selection of biological samples for examination in criminal proceedings: main stages and directions of research

The article considers the main stages and directions of research of sampling of biological samples for expert research in criminal proceedings. The analysis focuses on forensic and forensic aspects of this issue. It is stated that in the practice of detection and investigation of crimes in the early twentieth century, samples were taken for expert research, appropriate comparative studies were conducted, and sometimes this was of crucial legal importance. The hidden properties of human tissues and secretions began to be revealed only after scientists K. Landsteiner (1900-1901) and J. Janski (1907-1908) discovered group antigens in the blood. It was then that the blood was divided into four groups: 0 (1), A (II), B (III), $A B(I V)$. This first genetically polymorphic system allowed to determine the group affiliation of the studied objects and was the impetus for further advances in molecular biology and the development of new methods based on the study of genetic information - genotyping (DNA analysis), isofocusing, electrophoresis and others, which allows pre-trial investigation bodies to identify specific individuals, including by taking samples for comparative research. It was found that some scientific research on obtaining samples of biological origin in criminal proceedings was not conducted at all, although in recent years several scientific papers have been prepared, which investigated certain aspects of detection, removal, storage of traces (not samples) of biological origin, as well as conducting expert studies of traces and other objects of biological origin. Among the scientists it is worth mentioning the names of I.O. Aistova, A.G. Ivanova, T.M. Shamonova, K.V. Levchenko and O.S. Arutjunova. On the basis of the analysis of a condition and the basic directions of research of reception of samples for carrying out examination in criminal proceedings the periodization of occurrence and formation of views on reception

( Коропецька С. О., Смушак О. М., 2020 
of these samples is allocated. The need to conduct research on sampling of biological origin in criminal proceedings becomes especially relevant in connection with the adoption of the modern CPC of Ukraine, prepared taking into account international human rights standards and current requirements in the fight against crime.

Key words: biological samples, DNA analysis, examination, research, sampling.

Постановка проблеми та іï актуальність. Вимоги сьогодення ставлять перед органами досудового розслідування завдання щодо впровадження у систему доказів дедалі більш широких сучасних можливостей судових експертиз. Під час проведення досудового розслідування за матеріалами кримінального провадження у працівників слідчих підрозділів нерідко виникає необхідність у призначенні ідентифікаційних досліджень з обов'язковим направленням до експертної установи крім об'єктів експертного дослідження відповідних порівняльних зразків.

Слідами злочинів, що залишаються на місці події, тілі й одязі учасників злочинної події, часто $\epsilon$ об'єкти біологічного походження: індивідуальний запах людини, волосся, кров, сперма, вагінальні виділення, слина або їх фрагменти та ін. Наявність подібних об'єктів зумовлена, насамперед, злочинними діями осіб, які заподіюють тілесні ушкодження різного ступеня тяжкості потерпілим під час учинення грабежів, розбоїв, зґвалтувань, убивств та інших кримінальних правопорушень, а також активним опором потерпілої особи, боротьбою, яка супроводжується нерідко заподіянням ушкоджень зловмиснику.

Досягнення наук біологічного спрямування досить давно використовуються криміналістами під час розкриття і розслідування злочинів. Досвід використання технологій білкового та молекулярно-генетичного дослідження у практиці роботи правоохоронних органів переконливо свідчить про те, що завдяки цьому ефективність розслідування багатьох видів злочинів може бути суттєво підвищена. Водночас багато сучасних доробок достатньою мірою не знайшли свого відображення в методичних рекомендаціях та у рактичній діяльності правоохоронних органів.

Аналіз останніх досліджень i публікацій. Окремі кримінально-процесуальні і тактичні особливості отримання зразків біологічного походження у кримінальному провадженні досліджували вітчизняні та зарубіжні вчені: Т.В. Авер'янова, В.О. Гавриков, Н.А. Джангельдін, Н.І. Долженко, В.А. Жбанков, Г.Б. Карнович, О.В. Козак, Ю.А. Кудрявцева, Л.І. Мандрик,
І.Л. Петрухін, Р.Д. Рахунов, З.М. Соколовський та ін. Однак їхні наукові напрацювання не вичерпують усіх аспектів означеної проблематики. Зокрема, варто звернути увагу на історичні витоки відібрання зразків для експертизи, основні етапи та напрями криміналістичних та медичних досліджень.

Метою статті $\epsilon$ з'ясування основних етапів та напрямів дослідження відібрання зразків біологічного походження для експертизи у кримінальному провадженні.

Виклад основного матеріалу. Під час розслідування злочинів у слідчій практиці нерідко виникає необхідність отримання різного роду зразків для проведення експертизи. Отримані зразки слугують об'єктами, що використовуються для порівняльного дослідження з іншими об'єктами: речовими доказами, документами, живими людьми і трупами з метою їх ідентифікації або встановлення групової належності [1, с. 507]. Значну їх частку утворюють біологічні зразки - об'єкти крові, тканини та виділення, що відбираються у особи.

Уже у першій праці видатного вченого та родоначальника криміналістики Г. Гросса «Керівництво для судових слідчих, чинів загальної і жандармської полиції» (1892р.), перевиданої у 1908 р., розглядаються питання, пов'язані з виявленням, вилученням та дослідженням слідів, у главах XIII «Про сліди від людських ніг та інші» та XIV «Про сліди крові». Автором даються практичні рекомендації щодо виявлення різного роду слідів, їх вимірювання, вилучення, дослідження та збереження [2]. Стосовно слідів крові вчений відзначає: «До найважливіших доказів, зокрема у складних кримінальних справах, відносяться сліди від крові, які частіше за інших стають у справі найбільш суттєвими, якими $б$ незначними вони не здавалися з першого погляду. Саме під час огляду і оцінки слідів крові судовий слідчий може проявити всю свою наполегливість, енергію і властиву йому гостроту розуму, і саме тут, у цій сфері слідчої діяльності, відсутність цих якостей ставить на карту долю всієї справи» [2, с. 690].

Приховані ж властивості тканин і виділень людини стали виявляти лише після відкриття вченими К. Ландштейнером (1900-1901) та Я. Янським (1907-1908) групових антигенів у крові. Саме тоді кров розділили на чотири групи: 0(1), A(II), B(III), $\mathrm{AB}(\mathrm{IV})$. Ця перша генетично поліморфна система дала змогу визначати групову належність досліджуваних об'єктів та стала поштовхом до подальших досягнень у галузі молекулярної біології та розроблення новітніх методів, заснованих на вивченні генетичної інформації, - генотипоско- 
пії (ДНК-аналізу), ізофокусування, електрофорезу та інших, що дає змогу органам досудового розслідування встановлювати конкретних осіб, у тому числі шляхом відбирання зразків для порівняльного дослідження.

Можна констатувати, що у практиці розкриття та розслідування злочинів ще на початку XX ст. відбиралися зразки для експертних досліджень, проводилися відповідні порівняльні дослідження, і часом це мало вирішальне юридичне значення. Одним із перших, хто використав наукові відкриття в галузі медицини під час розкриття злочину, став приват-доцент Судово-медичного інституту м. Туріна Леоне Латтес, який у 1916 р. довів невинуватість у вчиненні вбивства злочинця-рецидивіста Альдо Петруччі, визначивши групу крові потерпілого та обвинуваченого, відібравши відповідні зразки останнього в тюрмі попереднього затримання та порівнявши їх зі слідами крові, вилученими з місця події [3, с. 43]. Слід зауважити, що після цієї справи Л. Латтес за покликанням став криміналістом у галузі судової медицини.

Незадовго після цього розкрив злочин таким самим способом російський професор судової медицини Попов, а згодом й інші [219, с. 45-47].

Ще одне відкриття, яке відіграло надалі виняткову роль під час проведення порівняльних експертних досліджень, здійснив у 1925 р. директор судово-медичного відділення Імператорського університету в Хокайдо К. Ямакамі. Він установив, що не лише кров володіє чотирма групами властивостей, а такі ж характеристики мають сперма, піт, сльози, жовч, материнське молоко та інші виділення людини [3, с. 83].

Однак діяльність з отримання зразків у той час законодавцем не регламентувалася, вочевидь через те, що навіть уже в повоєнні роки існуючі на той час методи встановлення групової належності крові не були досконалими, що призводило до помилок і неправосудних вироків [3]. Уперше порядок отримання зразків був передбачений КПК РРФСР 1960 р., а також КПК союзних республік. Законодавче закріплення отримання зразків - результат узагальнення слідчо-судової практики їх використання в судочинстві, що мало велике значення для вирішення цієї проблеми [4, с. 4]. Чимале значення при цьому мали публікації Г.Б. Карновича, Р.Д. Рахунова, Н.А. Джангельдіна та інших криміналістів, які у 50-х роках звернули увагу на необхідність правової регламентації отримання зразків для експертного дослідження та з'ясування їхнього місця у системі доказів.
У КПК УРСР від 28 грудня 1960 р. була передбачена стаття 199 «Отримання зразків для експертного дослідження», яка закріпила лише положення про те, що «у разі необхідності слідчий має право винести постанову про вилучення або відібрання зразків почерку та інших зразків, необхідних для експертного дослідження. Про відібрання зразків складається протокол. Зразки зберігаються за правилами зберігання речових доказів» [5]. Однак дана норма видається надто лаконічною, оскільки у ній, як бачимо, закріплене лише право слідчого на відібрання зразків для експертного дослідження, проте у яких саме суб'єктів, уже не вказується. Не дається також ні поняття зразків для експертного дослідження, ні їх видів тощо.

Згодом у теоретичних дослідженнях учених-криміналістів та процесуалістів дана прогалина була виправлена. Із закріпленням у КПК РРФСР 1960 р. та КПК союзних республік отримання зразків для експертних досліджень дискусії щодо цієї процесуальної дії пожвавилися. Чимало праць, в яких висвітлюються окремі їі аспекти, в юридичній літературі тих часів знаходимо таких учених, як Р.С. Бєлкін, А.І. Вінберг, А.В. Дулов, В.Я. Колдін, З.М. Соколовський та ін. Проте можна констатувати, що ґрунтовне дослідження цієї проблеми вперше здійснив видатний російський учений В.А. Жбанков, який тривалий час вивчав іï та в 1967 р. захистив кандидатську дисертацію на тему «Получение и использование образцов для сравнительного исследования» [6], а в 1969 р. видав і навчальний посібник.

Наукові доробки В.А. Жбанкова щодо тактики відбирання зразків для експертного дослідження залишалися основними рекомендаціями для слідчо-оперативних органів до 90-х років минулого століття, оскільки надалі окремих досліджень на монографічному рівні цієї проблематики не проводилося, а звернулися до цієї теми криміналісти вже з розпадом СРСР та прийняттям нових кримінально-процесуальних кодексів відповідних держав пострадянського простору.

Також викликали інтерес у науковців та практиків до криміналістичної ідентифікації фундаментальні відкриття у галузі біології та медицини. Із другої половини 80-х років у практику судово-медичної експертизи починають запроваджуватися методи молекулярної генетики, які дали змогу проводити порівняльні дослідження об'єктів біологічного походження. Революційним досягненням, що принципово по-новому дало змогу підійти до проблеми ідентифікації біологічного сліду, 
стало застосування методів аналізу ДНК, що дало можливість досліджувати безпосередньо молекулу ДНК, в якій закодовано всі біологічні ознаки людини.

У світі криміналістичний ДНК-аналіз визнаний одним із найбільш перспективних напрямів розвитку судових експертиз, а його результати сьогодні $\epsilon$ найбільш надійним доказом [7, с. 21].

Першою серед новітніх науковців, які звернулися до проблем відбирання зразків для експертного дослідження, слід назвати білоруську вчену Л.І. Мандрик, яка в 1991 р. захистила кандидатську дисертацію на тему «Процесуальні і криміналістичні аспекти отримання зразків для порівняльного дослідження» [8].

У 2000 р. в Москві захистила кандидатську дисертацію під назвою «Зразки для порівняльного дослідження і тактика їх отримання» Н.І. Долженко [9], у 2004 р. - В.О. Гавриков на тему «Отримання зразків для порівняльного дослідження» [10].

У них автори дослідили поняття, юридичну природу та класифікацію зразків для експертного дослідження, загальні питання отримання експериментальних зразків, а також особливості тактики отримання експериментальних зразків для окремих видів експертиз (матеріалознавчих, харчових) (Н.І. Долженко), використання спеціальних знань під час отримання зразків, забезпечення прав і законних інтересів особи під час їх отримання, а також деякі особливості отримання зразків біологічного походження (В.О. Гавриков).

У 2013 р. в Челябінську було захищено ще одну дисертацію - Ю.А. Кудрявцевою на тему «Отримання зразків для порівняльного дослідження в кримінальному судочинстві Росії (процесуальна природа, порядок, доказове значення)», в якій окрім загальних питань авторкою було досліджено особливості отримання зразків під час проведення судово-медичної експертизи трупа і медико-криміналістичних експертиз об'єктів біологічного походження та отримання експериментальних зразків для порівняльного дослідження у живих осіб [11].

Слід відзначити, що на тему «Одержання зразків для експертного дослідження у кримінальному судочинстві України» у 2011 р. було захищено дисертаційну роботу (О.В. Козак, науковий керівник B.І. Галаган). У ній проаналізовано одержання зразків для експертного дослідження в системі процесуальних дій за чинним тоді КПК України: з'ясовано поняття та підстави одержання зразків для експертного дослідження; здійснено класи- фікацію зразків для експертного дослідження та суб'єктів їх одержання; показано співвідношення одержання зразків для експертного дослідження з іншими процесуальними діями; досліджено процесуальний порядок одержання зразків для експертного дослідження (правову регламентацію і сутність одержання зразків для експертного дослідження; особливості одержання окремих видів зразків для експертизи; безпосереднє одержання зразків людини, що $\epsilon$ продуктом їі життєдіяльності; одержання зразків, що є результатом опосередкованої діяльності людини; одержання зразків предметів та їх частин); проведено порівняння процедури одержання зразків для експертного дослідження з кримінально-процесуальною практикою деяких країн СНД та міжнародно-правовими актами в галузі кримінального судочинства [12].

Окремих наукових досліджень, присвячених отриманню зразків саме біологічного походження у кримінальному провадженні, не проводилося взагалі, хоча за останні роки було підготовлено декілька наукових робіт, у яких досліджувалися окремі аспекти виявлення, вилучення, зберігання слідів (а не зразків) біологічного походження, а також проведення експертних досліджень слідів та інших об'єктів біологічного походження. Серед науковців варто назвати прізвища І.О. Аїстова, А.Г. Іванова, Т.М. Шамонової, К.В. Левченка та О.С. Арутюнова.

Висновки. На підставі аналізу стану та основних напрямів дослідження отримання зразків для проведення експертизи у кримінальному провадженні можна виділити таку періодизацію виникнення та формування поглядів на отримання цих зразків:

1) 1-й етап (поч. XX ст. - 50-ті роки XX ст.) формування поглядів на сутність та природу відбирання зразків для проведення експертного дослідження (Г.Б. Карнович, Р.Д. Рахунов, Н.А. Джангельдін);

2) 2-й етап (1960-1961 рр. ) - законодавче закріплення відбирання зразків у КПК РРФСР та союзних республік;

3) 3-й етап (60-ті роки XX ст.) - розвиток дискусій та початок фундаментальних досліджень із питань отримання зразків для експертизи (Р.С. Бєлкін, А.І. Вінберг, А.І. Долженко, А.В. Дулов, В.А. Жбанков, В.Я. Колдін, І.Л. Петрухін, 3.М. Соколовський);

4) 4-й етап (90-ті роки XX ст. - дотепер) - формування новітніх поглядів на природу отримання зразків для проведення експертного дослідження 
та їх законодавче закріплення у КПК України та інших країн СНД.

Вивчення стану наукового розроблення проблематики отримання зразків біологічного походження для проведення експертних досліджень свідчить про те, що до цього часу вона не була предметом самостійних досліджень учених-криміналістів. Деякі аспекти заявленої теми фрагментарно висвітлено у деяких наукових працях. Особливо актуальною необхідність проведення такого дослідження видається у зв'язку з прийняттям сучасного КПК України, підготовленого з урахуванням міжнародних стандартів із прав людини та вимог сьогодення у боротьбі зі злочинністю. Насамперед це стосується відбирання зразків біологічного походження 3 метою проведення порівняльних досліджень, зокрема у галузі молекулярної біології, із застосуванням новітніх методів, заснованих на вивченні генетичної інформації.

\section{Література}

1. Кримінальний процесуальний кодекс України : науково-практичний коментар / відп. ред. С.В. Ківалов, С.М. Міщенко, В.Ю. Захарченко. Харків : Одіссей, 2013. 1104 с.

2. Гросс Г. Руководство для судебных следователей как система криминалистики ; новое изд., перепеч. с изд. 1908 г. Москва : ЛексЭст, 2002. $1088 \mathrm{c}$.

3. Торвальд Ю. Криминалистика сегодня. Развитие судебной серологии / пер. с нем. Москва : Юрид. лит., 1980. 200 с.

4. Жбанков В.А. Образцы для сравнительного исследования в уголовном судопроизводстве : учебное пособие. Москва : Высшая школа МВД СССР, 1969. 60 c.

5. Кримінально-процесуальний кодекс України : станом на 10 жовт. 2007 р. Офіц. видання. Київ : Велес, 2007. 168 с.

6. Жбанков В.А. Получение и использование образцов для сравнительного исследования : авто- реф. дис. ... канд. юрид. наук : 12.00.09. Москва, 1967. 25 с.

7. Гавриков В.А. Получение образцов для сравнительного исследования : автореф. дис. ... канд. юрид. наук : 12.00.09. Москва, 2004. 22 с.

8. Мандрик Л.И. Процессуальные и криминалистические аспекты получения образцов для сравнительного исследования : автореф. дис. ... канд. юрид. наук : 12.00.09. Минск, 1991. 18 с.

9. Долженко Н. И. Образцы для сравнительного исследования и тактика их получения : дис. ... канд. юрид. наук : 12.00.09. Москва, 2000. 169 с.

10. Гавриков В.А. Получение образцов для сравнительного исследования : дис. ... канд. юрид. наук : 12.00.09. Москва, 2004. 171 с.

11. Кудрявцева Ю.А. Получение образцов для сравнительного исследования в уголовном судопроизводстве России (процессуальная природа, порядок, доказательственное значение) : автореф. дис. ... канд. юрид. наук : 12.00.09. Челябинск, 2013. 30 с.

12. Козак О.В. Одержання зразків для експертного дослідження у кримінальному судочинстві України : дис. ... канд. юрид. наук : 12.00.09. Донецьк, 2011. 207 c.

Коропецька С. O., кандидат юридичних наук, доцент кафедри кримінального процесу та криміналістики Івано-Франківського юридичного інституту Національного університету «Одеська юридична академія»

Смушак О. М., кандидат юридичних наук, старший викладач кафедри кримінального права та кримінології Івано-Франківського юридичного інституту Національного університету «Одеська юридична академія» 